Article

\title{
Injury/Fatality-Causing Incidents Involving the Rearward Movement of Agricultural Machinery: Types, Causes, and Preventive Measures
}

\author{
Shawn G. Ehlers * and William E. Field \\ Department of Agricultural and Biological Engineering, Purdue University, 225 South University Street, \\ West Lafayette, IN 47907, USA; field@purdue.edu \\ * Correspondence: sehlers@purdue.edu; Tel.: +1-800-825-5264 \\ Academic Editor: Dennis Murphy \\ Received: 25 May 2016; Accepted: 19 January 2017; Published: 8 February 2017
}

\begin{abstract}
The research reported here sought to more fully understand the types and causative factors of injury/fatality incidents resulting from the rearward-movement of tractors and other self-propelled agricultural machinery, with the view that such findings might lead to the development, improvement, and/or better utilization of safety procedures, design principles, and technologies that would prevent-or at least markedly reduce-their occurrence. Thus, the scope of this study focused only on rearward-travel (not mechanical malfunction) incidents, and principally on agricultural equipment (although cases involving similar equipment in industrial or construction settings were also drawn upon). Applying these two criteria, a search of published and online sources uncovered more than 100 documented cases, 35 of which could clearly be identified as rearward-movement incidents, of which $28(80 \%)$ were fatal. Each of these 35 cases were then assessed, based on the type of machine, type of worksite, and type/description of incident (i.e., 'scenario'), which fell into one of three distinct categories or classifications-(1) co-worker run over/crushed/otherwise injured because operator loses visual contact with co-worker; (2) bystander run over/crushed/otherwise injured because operator is unaware of bystander's presence; and (3) operator run over/crushed/otherwise injured because operator loses visual contact with, or is unaware of, a stationary object or a hazard. Then, from each scenario, a representative incident (i.e., case study) was selected for a more in-depth analysis. The collective findings, from these three case studies and all 35 machinery rearward-movement incidents, were as follows: (1) The 'victim' could be the machine operator as well as a co-worker or a bystander; (2) The specific site of the co-worker or bystander injury/fatality was at the base of the machine's rear tires or tracks, at the hitching point, or behind a towed implement; (3) The specific cause was loss of visual contact between the operator and co-worker/bystander due to visual obstruction, the operator's physical limitations, or the operator's and/or bystander's lack of alertness. To reduce the likelihood of future occurrences of agricultural machinery rearward travel-related incidents, preventive measures aimed at addressing the key causative factors for each scenario are offered.
\end{abstract}

Keywords: blind spot; bystander; backover; detection; case study; machine vision; runover; self-propelled machinery; visibility

\section{Introduction}

Attention given to rearward motion-related runovers of persons (particularly children) present in 'blind spots' behind motor vehicles, has raised the question of the impact of similar events involving agricultural machinery [1,2]. Such equipment is not covered by current motor vehicle regulations, or by OSHA workplace safety standards that are enforced in the construction industry [3]. A search for the 
sources of agricultural injury data revealed few reports that specifically addressed incidents involving the runover or crushing of bystanders and co-workers in the rearward path of agricultural machines, especially those that, by their design, limited the operator's rearward vision. No published summary of this data was found. However, incidents were identified in on-line reports in which runover/crushing occurred, mainly due to the loss of visual contact between the operator and an individual in close proximity of the machine, or due to an object in the rearward path of the machine. Examples of such machines are larger tractors, combines, skid-steer loaders, and self-propelled sprayers.

This article attempts to (1) enumerate the risks associated with the rearward travel of agricultural machinery; (2) identify the similarities in documented incidents that would aid in recognition of the contributing factors; and (3) suggest possible solutions for reducing future occurrences. Some 35 case studies are summarized and, based on analysis, recommendations are made. For example, the necessity of operator 'walk-arounds' prior to moving large machinery was emphasized.

\section{Background}

An extensive review of the literature was conducted, including published and online data related to runover/crushing incidents involving motor vehicles, construction equipment, loading docks, and agricultural equipment. Key causative factors, recommended operator preventive practices, and assistive technologies were identified, that could be significant in agricultural settings. Case studies involving agricultural equipment were extracted and examined from those documented incidents that reflected the most frequent type of injury/fatality-causing situations.

No publically accessible U.S. research was found that specifically reported on the frequency and severity of injuries associated with the rearward travel of agricultural equipment. A review of the data sources that did distinguish between the types of machinery incidents, revealed that no cases separated the 'rearward runovers', from the broader category of 'runovers.' In many of the reported cases, the direction of travel of the machinery could not be determined.

Even though, for several decades, the problems relating to rearward runover/crushing have been well understood in the mining and construction industries, this understanding has apparently not 'transitioned' to agricultural workplaces. For example, OSHA standards have, for many years, required audible backup alarms on equipment used at manufacturing and construction sites; however, agricultural equipment is generally exempt from those requirements [3]. Consequently, almost no agricultural machines currently being sold in the U.S. are equipped with such devices; whereas similar (even the same) equipment being sold in the European market is likely to be so equipped, because of both Europe's health and safety standards, and corporate insurer mandates [4].

According to the U.S. Bureau of Labor Statistics, agriculture ranks as having the highest fatal work injury rate of any industry-22.2 persons per 100,000 full-time equivalent workers [5]. Agricultural machinery was identified as the primary cause of most farm work-related fatalities, with runover or crushing being the second most frequent type of machinery-related fatal incidents, exceeded only by tractor rollovers [6]. In most documented runover incidents, the victim fell from the machine and was run over by either the machine itself, or the trailing implement; yet in other cases, the operator failed to see a co-worker or bystander before initiating the rearward movement. The proportion of these incidents involving rearward travel could not be ascertained from the reports, due to a lack of information.

\section{Methods and Findings}

\subsection{Identified Rearward Movement-Related Incidents}

Cases were obtained via facilitation of a news clipping service, focused searches of obituaries, news outlets (radio, television, newspaper and web-based), U.S. governmental agency databases (OSHA, DOL, NIOSH), records of post-civil litigation, and university sponsored agricultural incident databases. The search for documented incidents was primarily focused in the U.S.; however, two international 
cases were present in the data sources that fit the criteria. The rearward incident cases reviewed here only include those which clearly identified the key contributor as being operator error relating to poor visibility, not mechanical malfunction of the machine (e.g., failing clutch, brakes, hydraulics). Applying that criterion, of the more-than-100 machinery-related incidents documented from published and online farm-related injury data sources, 35 were clearly identified as being 'rearward-travel runover/crushing' (see Appendix A). Of the 35 cases identified, 23 occurred at agricultural worksites, with similar frequencies being documented at construction, industrial, logging, and landfill sites. These 35 cases are listed in Tables 1-3, in which the following data are summarized: type of machine involved, type of worksite, type and description of incident—or appropriate 'scenario' (i.e., one of three general categories defining type of incident and person(s) involved), age, gender, and resulting fatality (yes/no). The three different scenarios are as follows:

- Scenario 1. Incident in which the operator loses visual contact with a known assistant/co-worker to the rear of the machine during backup, resulting in runover or crushing of the assistant/co-worker.

- Scenario 2. Incident in which the operator is unaware of a bystander being present to the rear of the machine during backup, resulting in runover or crushing of the bystander.

- Scenario 3. Incident involving the operator only, in which he/she backs the machine into a stationary object (e.g., building, tree, other equipment) or hazard (e.g., overhead power line, ditch), resulting in severe injury or death of the operator.

Although by no means comprehensive, these 35 documented cases, collected from 1992-2016 (with $75 \%$ of the incidents occurring within the past 10 years), yielded sufficient data to allow an analysis that would provide a better understanding of the issues. Considering that $80 \%$ of the documented cases were fatal, it is believed that a much larger number of non-fatal incidents go unreported, or cannot be identified from the available data. Tables 1-3 represent cases identified in Scenarios 1, 2 and 3, respectively.

Table 1. Summary of scenario 1 rearward-runover incidents.*

\begin{tabular}{|c|c|c|c|c|c|c|}
\hline Type of Machine & $\begin{array}{c}\text { Type of } \\
\text { Worksite }\end{array}$ & Scenario $* *$ & Description of Incident & $\begin{array}{c}\text { Fatal } \\
\text { (Yes/No) }\end{array}$ & $\begin{array}{l}\text { Victim } \\
\text { Age }\end{array}$ & $\begin{array}{l}\text { Victim } \\
\text { Gender }\end{array}$ \\
\hline Pickup truck & Agriculture & 1 & $\begin{array}{l}\text { Operator crushed assistant while } \\
\text { hitching wagon }\end{array}$ & Yes & 39 & Male \\
\hline Semi-tractor/trailer & Agriculture & 1 & $\begin{array}{l}\text { Operator crushed assistant while } \\
\text { positioning trailer }\end{array}$ & Yes & 56 & Male \\
\hline Tractor & Agriculture & 1 & Operator backed over assistant & Yes & -- & Male \\
\hline Tractor & Agriculture & 1 & $\begin{array}{l}\text { Operator backed over assistant } \\
\text { while hitching implement }\end{array}$ & Yes & 81 & Male \\
\hline Truck/trailer & Agriculture & 1 & $\begin{array}{l}\text { Operator crushed assistant while } \\
\text { positioning trailer }\end{array}$ & Yes & 12 & Male \\
\hline Front loader & Construction & 1 & $\begin{array}{l}\text { Operator lost visual contact and } \\
\text { backed over assistant }\end{array}$ & Yes & -- & Male \\
\hline Tractor & Industrial & 1 & $\begin{array}{l}\text { Operator crushed assistant while } \\
\text { hitching implement }\end{array}$ & No & 49 & Male \\
\hline Tractor & Agriculture & 1 or 2 & $\begin{array}{l}\text { Operator backed over wife in } \\
\text { livestock feeding area }\end{array}$ & Yes & 50 's & Female \\
\hline Tractor & Logging & 1 or 2 & $\begin{array}{l}\text { Operator crushed assistant in } \\
\text { "cramped work environment" }\end{array}$ & No & -- & Male \\
\hline Tractor & -- & 1 or 2 & Operator backed over victim's leg & No & 18 & Male \\
\hline
\end{tabular}

Notes: * Documented sources identified in Appendix A; ${ }^{* *}$ Scenario explanations in text above. 
Table 2. Summary of scenario 2 rearward-runover incidents.*

\begin{tabular}{|c|c|c|c|c|c|c|}
\hline $\begin{array}{l}\text { Type of } \\
\text { Machine }\end{array}$ & $\begin{array}{c}\text { Type of } \\
\text { Worksite }\end{array}$ & Scenario ** & Description of Incident & $\begin{array}{c}\text { Fatal } \\
\text { (Yes/No) }\end{array}$ & $\begin{array}{l}\text { Victim } \\
\text { Age }\end{array}$ & $\begin{array}{l}\text { Victim } \\
\text { Gender }\end{array}$ \\
\hline Tractor & Agriculture & 2 & Operator backed over unobserved child & Yes & 1 & Male \\
\hline Tractor & Agriculture & 2 & Operator backed over unobserved child & Yes & 5 & Male \\
\hline Tractor & Agriculture & 2 & $\begin{array}{l}\text { Operator backed over unobserved } \\
\text { assistant with grain wagon }\end{array}$ & Yes & 65 & Male \\
\hline Tractor & Agriculture & 2 & $\begin{array}{l}\text { Operator backed over assistant while } \\
\text { hitching implement }\end{array}$ & Yes & 12 & Male \\
\hline Tractor & Agriculture & 2 & $\begin{array}{c}\text { Operator backed over coworker } \\
\text { servicing implement }\end{array}$ & No & 28 & Male \\
\hline $\begin{array}{l}\text { Cotton module } \\
\text { transport }\end{array}$ & Agriculture & 2 & $\begin{array}{l}\text { Operator backed over assistant while } \\
\text { positioning equipment }\end{array}$ & Yes & 35 & Male \\
\hline $\begin{array}{l}\text { Combine } \\
\text { Harvester }\end{array}$ & Agriculture & 2 & $\begin{array}{c}\text { Operator backed over brother in } \\
\text { corn field }\end{array}$ & Yes & 63 & Male \\
\hline Skid steer & Agriculture & 2 & $\begin{array}{l}\text { Operator backed over wife while exiting } \\
\text { storage facility }\end{array}$ & Yes & 65 & Female \\
\hline Front loader & Construction & 2 & $\begin{array}{c}\text { Operator backed over coworker working } \\
\text { near by }\end{array}$ & Yes & 31 & Male \\
\hline Front loader & Construction & 2 & $\begin{array}{l}\text { Operator backed over unobserved } \\
\text { coworker }\end{array}$ & Yes & 19 & Male \\
\hline Grader & Construction & 2 & $\begin{array}{l}\text { Operator backed over unobserved } \\
\text { coworker }\end{array}$ & Yes & 32 & Male \\
\hline Skid steer & Construction & 2 & $\begin{array}{l}\text { Operator backed over unobserved } \\
\text { coworker }\end{array}$ & Yes & 45 & Male \\
\hline Tractor & Construction & 2 & $\begin{array}{c}\text { Operator backed over unobserved } \\
\text { coworker }\end{array}$ & Yes & -- & Male \\
\hline Tractor & Industrial & 2 & $\begin{array}{c}\text { Operator unloading cargo backed over } \\
\text { unobserved coworker }\end{array}$ & No & -- & Male \\
\hline $\begin{array}{l}\text { Compacting } \\
\text { tractor }\end{array}$ & Landfill & 2 & $\begin{array}{c}\text { Operator backed over unobserved } \\
\text { victim }\end{array}$ & Yes & 31 & Male \\
\hline $\begin{array}{l}\text { Compacting } \\
\text { tractor }\end{array}$ & Landfill & 2 & $\begin{array}{l}\text { Operator backed over unobserved } \\
\text { coworker }\end{array}$ & Yes & 55 & Male \\
\hline
\end{tabular}

Notes: ${ }^{*}$ Documented sources identified in Appendix A; ${ }^{* *}$ Scenario explanations in text above.

Table 3. Summary of scenario 3 rearward-runover incidents.*

\begin{tabular}{|c|c|c|c|c|c|c|}
\hline $\begin{array}{l}\text { Type of } \\
\text { Machine }\end{array}$ & $\begin{array}{c}\text { Type of } \\
\text { Worksite }\end{array}$ & Scenario ** & Description of Incident & $\begin{array}{c}\text { Fatal } \\
\text { (Yes/No) }\end{array}$ & $\begin{array}{l}\text { Victim } \\
\text { Age }\end{array}$ & $\begin{array}{l}\text { Victim } \\
\text { Gender }\end{array}$ \\
\hline Combine & Agriculture & 3 & $\begin{array}{l}\text { Operator backed into overhead } \\
\text { power line }\end{array}$ & Yes & 20 's & Male \\
\hline Tractor & Agriculture & 3 & $\begin{array}{l}\text { Operator fell from tractor and was } \\
\text { backed over }\end{array}$ & No & 60 's & Male \\
\hline Tractor & Agriculture & 3 & $\begin{array}{c}\text { Operator backed into low barn door } \\
\text { header (No ROPS) }\end{array}$ & Yes & 40 's & Male \\
\hline Tractor & Agriculture & 3 & Operator backed over embankment & Yes & 74 & Male \\
\hline Tractor & Agriculture & 3 & $\begin{array}{l}\text { Operator using loader attachment } \\
\text { backed into tree }\end{array}$ & Yes & 65 & Male \\
\hline Tractor & Agriculture & 3 & Operator backed over embankment & Yes & 74 & Male \\
\hline Tractor & Agriculture & 3 & Operator backed into stationary hazard & Yes & 65 & Male \\
\hline Tractor & Agriculture & 3 & Operator backed over embankment & Yes & 73 & Male \\
\hline Skid steer & Construction & 3 & Operator backed over embankment & Yes & 43 & Male \\
\hline
\end{tabular}

Notes: * Documented sources identified in Appendix A; ${ }^{* *}$ Scenario explanations in text above.

\subsection{Representative Scenario Cases Studies}

Of the 35 cases reviewed, one from each of the three scenarios was selected as being representative of the results common to the other incidents in that scenario, and is summarized below (incident location and victim identity are excluded for privacy reasons):

- Scenario 1 example. On 3 May 2013, an 81-year-old man died after being backed over by a tractor, operated by a 68 -year-old male. The victim was helping to hitch a mowing attachment when the operator lost visual contact with him as he (the assistant) lost his balance and fell. The county coroner said, "He was crushed when the tractor backed over the top of him. He died instantly" [7]. 
- Scenario 2 example. On 9 September 2010, a 1-year old died after being backed over by a tractor, operated by his father. The victim was playing nearby with his siblings and under supervision of their mother, while the father was doing landscaping work around their home. The mother had briefly walked away and, unbeknownst to the father, the victim stepped into the space behind the tractor, which resulted in the incident [8].

- Scenario 3 example. On 3 November 2014, a 65-year-old man, who was moving a big round hay bale with a tractor in reverse, could not see the aluminum round-bale feeding ring behind him, because the bale was obstructing his view. The county sheriff spokesman said that when backing up, the tractor rolled over the feeding ring, causing it (the ring) to spring up off the ground, striking the operator in the head. Despite the victim's wife being present, she could do nothing to revive him [9].

\subsection{Case Study Demographics}

When subdivided by scenario type (Figure 1), the majority (54\%) of incidents occurred when the operator was unaware of the presence of a bystander. This often involved the presence of a young child or co-worker who were in a reportedly unsafe location, were poorly trained on the dangers of their surroundings, or assumed that the operator was aware of their presence. The second most frequent incident scenario resulted from the loss of visual contact with a known co-worker. Often, the co-worker was portrayed as not having followed proper hitching instructions from the operator, or had rushed the intended task (did not wait to establish proper communication with the operator). While heightened levels of operator visibility would not affect all of the actions of a co-worker, it would conceivably allow for a quicker reaction to dangerous situations. Lastly, incidents involving only the operator, commonly involved an individual with a high level of experience, who appeared to be complacent with the surrounding dangers, as many of the tasks being performed by the operator were repetitive in nature.

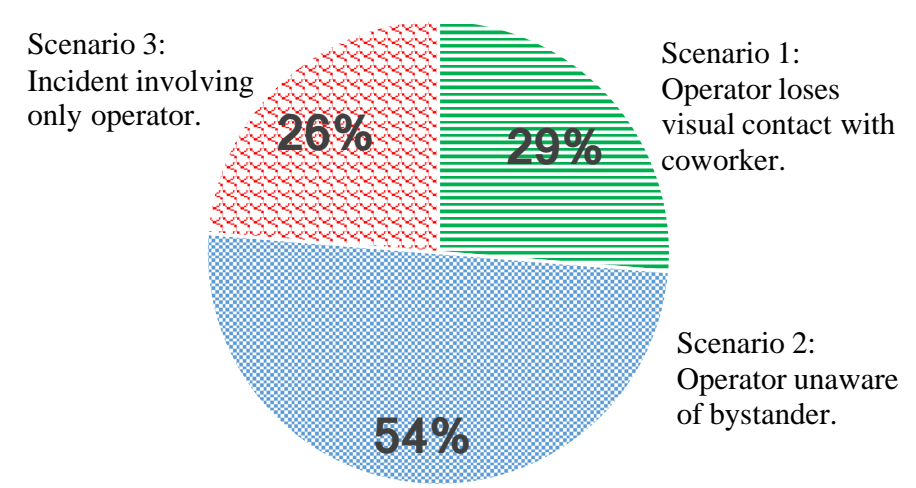

Figure 1. Incident occurrence by scenario type.

A second identifiable characteristic of the victims, when considering the incident scenario type, was their age. The average age of the victims in scenario one, during which the operator loses visual contact with the co-worker, was 44 years. Scenario two entailed $54 \%$ of the incidents reported in this study, which occurred when the operator was unaware of a bystander at the rear of the machine. The average age of the victims in this category was 34 years, with a range of one to 65 years. This category included the most frequent occurrences of incidents involving children under the age of 16 years. The average age of the victims in incidents involving only the operator, scenario three, was 59 years. This nearly equaled the age of the average U.S. farmer, which is 58 years, according to the 2012 USDA Census of Agriculture [10].

Of all cases collected, $80 \%$ were fatal, with $6 \%$ of the fatalities/injuries being female, who make up $14 \%$ of the principal farm operators in the U.S. [10]. While all of the machines identified in 
this study were common types that would be found on U.S. farms, $63 \%$ of the cases occurred in agricultural settings.

\section{Discussion and Recommendations}

Relative to all 35 identified rearward-runover/crushing incidents, the most common recommendations made by various investigating entities, established to assure safe and healthful working conditions for both men and women by focusing on setting and enforcing standards, and by providing training, outreach, education, and assistance. Reducing or eliminating such incidents dealt with the need for operators to notify bystanders, the provision of operator instructions requiring safe rearward travel, the execution of safe work practices, and the use of barriers and technologies. For the above three case studies, the following specific recommendations were developed to address, what was determined as being, the causative factor(s) in each of the representative scenarios:

- Scenario 1 recommendations. (1) Operator should stop immediately upon losing visual contact with assistant [11]; (2) Proper hitching methods should be followed [12]; (3) Assistant should maintain a safe distance from the path of the tractor/implement and should direct operator using hand signals for proper alignment [13]; (4). Tractor should be put into park and/or engine shut off when assistant approaches area to complete hitching [12]; (5) Additional assistive viewing devices, such as mirrors and cameras, should be utilized to eliminate blind spots in dangerous proximity of machinery [14].

- Scenario 2 recommendations. (1) All individuals in proximity of machinery should be informed of dangers associated with machine operation via prior training, machine spotter, alarms, etc. [15]; (2) Additional assistive viewing devices, such as mirrors and cameras, should be utilized to eliminate blind spots in dangerous proximity of machinery [16]; (3) A backup alarm system would alert individuals of reversing machinery [17].

- Scenario 3 recommendations. (1) Additional assistive viewing devices, such as mirrors and cameras, should be utilized to eliminate blind spots in dangerous proximity of machinery [14]; (2) Tractors should be equipped with a roll-over protective structure [18]; (3) Addition of a canopy or Forward Overhead Protection System (FOPS) can protect operator from elements and offer additional structure of protection.

All three scenarios include, among the recommendations, the ability to 'notify' (i.e., alert) those individuals most likely to be involved with or near machinery processes-namely, the bystander/assistant and the operator. Following, is a discussion of the most important ways that this can be accomplished for each of these individuals when it comes to machinery rearward movement.

\subsection{Ways of Alerting the Bystander/Assistant}

Backup alarms. Bystanders are perhaps best 'notified' by backup alarms. These devices are required by OSHA in industries that qualify for oversight, and must emit a "signal alarm distinguishable from the surrounding noise level" while machinery is operated in reverse [3]. However, they provide no benefit to the operator and, in fact, may be distracting or overpower sounds that he/she needs to hear; also, they are often disabled, are not repaired if malfunctioned, or become overwhelming or disorienting when multiple-operating machines are present [19]. OSHA standards that require certain operating procedures, such as safely positioned observers, and safety devices such as backup alarms for most worksites, are not enforceable in agricultural operations that employ 10 or fewer people [20]. In other words, this leaves most agricultural workers exposed to a risk of runover, well recognized in other industries.

Safety training. OSHA standard 1926.21(b) (2) reads, “The employer shall instruct each employee in the recognition and avoidance of unsafe conditions and the regulations applicable to his work environment to control or eliminate any hazards or other exposure to illness or injury." In other words, the training of employees to recognize hazards is crucial to their safe working conditions. As noted in 
OSHA Standard 1926.601(b), this includes hazards associated with the movement of equipment at a worksite [17]. Again, these regulations are not enforceable at most agricultural worksites. Numerous NIOSH FACE reports reviewed for this paper indicated that even though employees were provided such training and safety measures, reviewed on a regular basis, incidents still occurred, indicating a disconnection between reality and an ideal working situation.

\subsection{Ways of Alerting the Operator}

Operators can rely on multiple avenues for detecting hazards in areas surrounding their machines. The simplest of these is a visual examination of the space around the machine. Proven technologies are also available to assist one in observing the surrounding areas (especially rearward), including interior and exterior extended-arm mirrors, proximity detectors, and camera/display monitor systems.

Mirrors. Mirrors are widely used, reliable, inexpensive, and relatively robust, if attached to breakaway mounting fixtures. When properly placed and adjusted, operators were found to work in a more comfortable zone of posture, have higher working rates, have better control of their work, and more quickly detect faults in their equipment [21]. They do have potential drawbacks, however, including image distortion, improper adjustment, and unseen blind spots. Image distortion can be caused by vibration, convexity, and foreign material on the surface [21]. Improper adjustment is a problem because manually adjusting exterior extended-arm mirrors is usually a two-person job, yet still doesn't allow for sufficient view of all critical areas, particularly the hitching zone. Unseen blind spots persist, especially in close proximity to the vehicle and in the hitching area, even with properly adjusted mirrors. Lund et al. reported that, "While (the tractor) driver can make allowances for the poor frontal vision and possibly the rear visibility on either side of the tractor is close to zero, mirrors help but it is easy for a bicycle or motorcycle to be completely out of vision" [22].

Proximity detectors. Increasingly utilized in the automotive industry, this technology allows for the detection of an obstacle within a calibrated range of its sensors. Audible (and sometime visible) alerts warn the operator of objects within close proximity of the sensor(s) by emitting a beeping tone that beeps faster, until becoming continuous when the object is dangerously close. However, these devices can give false readings where terrain varies and also must be deactivated with an implement in tow. Because varying terrain and the presence of implements are commonplace in farming, agricultural applications of proximity detectors have not been adapted as the best avenue for preventing rearward travel incidents-at least at this point in time.

Camera/display monitor systems. Camera monitoring systems offer users flexibility in placement, durability, ease of use, and affordability—all while efficiently increasing operator visibility to levels that are unattainable with an array of mirrors [16]. Camera systems are currently used in industries such as construction and mining, and will be required on all new U.S. on-highway vehicles under 10,000 pounds by the year 2018 [23]. Agricultural applications allow operators to monitor otherwise low visibility areas surrounding machinery and hitched implements, while maintaining a forward operator posture. Proper placement of one or multiple cameras provides assistance in monitoring the hitching process, tank levels, gauges/instruments, and machine 'faults' often out of view of the operator, and, most importantly, in detecting the presence of any bystanders and hazards.

Noted weaknesses with some camera systems relate to image disorientation, depth-perception, and image clarity. Image disorientation is sometimes encountered while course correcting, based upon the camera display. Otherwise known as 'image mirroring', disorientation occurs because the perceived direction of course correction is the opposite to what appears in the display (similar to reading words in a mirror). Many manufacturers recognize this issue and offer corrective options in the display menu that tailor camera systems to the intended task. Depth perception is often difficult, as a wide-angled camera lens can distort images. Some camera models are equipped with a grid, which is overlaid on the image, allowing the operator to associate the grid lines with known distances, from the mounted location of the camera. Image clarity is critical for the ability of the operator to make informed decisions about what is seen in the camera system. High-definition (HD) systems provide the best image clarity, 
while low-resolution systems provide images that are pixilated, thus less clearly identifying detail in the display. It is important to pair camera and display capabilities appropriately, meaning that a display unit must have the capability of exhibiting the resolution of the image that the paired camera provides, and vice versa. Dust and debris are common contributors to image clarity issues. Whether the particles are suspended in the working environment or collected upon the lens, decreased functionality will be observed. It is recommended that all camera systems feature waterproof exterior hardware, to allow for routine cleaning and the removal of foreign matter. Lastly, image clarity is highly subject to the quantity of light available. Too little or too much light will adversely affect the operator's ability to effectively use the system. Poor placement, low-angled sun, and/or poorly placed exterior lighting can all produce image glare, as a result of too much light. Too little light will not allow for the sufficient identification of hazards; however, similar effects are observed with mirrors.

\subsection{Hitching Process Protection for the Assistant}

Prior to moving an agricultural machine, the operator should conduct a 'walk-around' of both the machine, and any associated implement (either hitched or to be hitched), in order to identify possible hazards that may not be visible from the operator station [12]. Hitching is a dangerous process, especially if done by an assistant between the machine and the implement-and thus in the operator's blind spot. To avoid that situation, it's recommended that a hitching procedure be followed, which allows the assistant, through the use of appropriate standard hand signals and audible commands, to guide the operator in positioning the machine, while remaining outside of the machine's rearward-movement path [13]. When the vehicle reaches close proximity to the hitching point, it should be put into 'park' or shut off, and the key should be removed. The assistant then makes any necessary adjustments, returns to his position outside of the machine's path of movement, and proceeds to direct the operator by using hand signals to complete the hitching process. In some cases, the machines are so large that radio communications should be considered to aid in positioning the equipment, thus preventing a co-worker from having to enter a space outside of the operator's line of vision.

Also vital to the safety of those involved, is the steadiness of the implement being hitched, which, if not stable, can become dangerous if bumped. To prevent unintended movement of the implement, its wheels should be chocked, or if a parking brake is equipped, it should be engaged; it should also be equipped with sturdy, easily adjustable jack stands.

Furthermore, it is recommended that implements are equipped with hitches that accommodate adjustments for misalignment to reduce or eliminate the need of an assistant to stand in dangerous proximity, between the vehicle and the implement [24]. These accommodations are available in many forms, such as telescoping tongues, telescoping arms, lateral and vertical adjustability on a three-point hitch, and/or tapered or wedge-shaped guides (often used on quick hitches).

\section{Conclusions}

Comprehension of incidents involving rearward travel of agricultural machinery is often problematic, in part, due to the incident-recording agency's categorical classification of 'runover.' Our investigation of 35 documented cases of such 'runovers' revealed the common factors that contributed to fatalities: the operator not being able to maintain visual contact with a known assistant, the operator not realizing the presence of an unknown bystander in dangerous proximity, and the operator not being able to identify a stationary object or hazard.

Additional research will be needed to more fully understand the complexity of runover incidents, and thus better evaluate potential solutions for reducing future occurrences. However, it seems that those solutions would likely involve modifications of equipment and/or addition of aiding technologies such as properly positioned mirrors, proximity sensors, camera/monitor systems, backup alarms, and autonomous camera/sensor-based intervention's, that would inform both the operator 
and the bystander of the potential hazards in close proximity of their location. The inclusion of the findings reported in this study, into agricultural training curricula and resources, is also recommended.

Acknowledgments: This study was supported by Purdue University's Agricultural Safety and Health Program. Publication was made possible, in part, with funding from the U.S. Department of Agriculture, National Institute for Food and Agriculture, Special Project \# 2011-41590-30936.

Author Contributions: Shawn G. Ehlers and William E. Field conceived and designed the experiments which were conducted by Shawn G. Ehlers. Shawn G. Ehlers performed the data collection and analyzed the data; and Shawn G. Ehlers and William E. Field wrote the paper.

Conflicts of Interest: The authors declare no conflict of interest.

\section{Nomenclature}

The key 'investigating agencies' cited in this report are:

NIOSH-National Institute for Occupational Safety and Health (a division of the U.S. Department of Health and Human Services' Centers for Disease Control and Prevention), whose purpose is "to develop new knowledge in the field of occupational safety and health to transfer that knowledge into practices";

PAMI-Prairie Agriculture Machine Institute, a free-for-service/government-funded applied research, development, and testing organization, serving agriculture and industry in Western Canada;

ASABE-American Society of Agricultural and Biological Engineers, an educational and scientific organization dedicated to the advancement of engineering applicable to agricultural, food, and biological systems; OSHA - Occupational Safety and Health Administration (a division of the U.S. Department of Labor)

\section{Appendix A}

\section{Sources of the 35 Clearly Identified Rearward Travel-Related Injury Incidents}

Following the sources of information on the 35 injury- or fatality-causing incidents that were clearly identified as involving the rearward movement of agriculture-related machinery. (Note: Some of these sources contained the reports on more than one incident.)

\begin{tabular}{|c|c|}
\hline Arizona Daily Sun (2011) & $\begin{array}{l}\text { Child Run over, Killed by Tractor. Flagstaff, AZ, USA. Available online: } \\
\text { http://azdailysun.com/news/local/child-run-over-killed-by-tractor/article_dd9e19be- } \\
\text { ca37-5488-9b4a-9c098b801665.html (accessed on } 30 \text { December 2014). }\end{array}$ \\
\hline Dublin.ie (2014) & $\begin{array}{l}\text { Nolan, Dnal. Man Injured under Tractor; Independent House: Dublin, Ireland, } 2014 . \\
\text { Available online: http://www.independent.ie/regionals/kerryman/news/man-injured- } \\
\text { under-tractor-30106121.html. (accessed on } 7 \text { April 2016). }\end{array}$ \\
\hline Field, W.E. (2016) & Ehlers, S.G. (Purdue University, West Lafayette, IN, USA). Personal communication, 2016. \\
\hline Fresno Bee (2008) & $\begin{array}{l}\text { Fresno Bee. Tractor Runs over Worker; Fresno Bee: Fresno, CA, USA, 2008. Available online: } \\
\text { www.fresnobee.com } / 2008 / 07 / 07 / 715675 / \text { news-briefs.html\#storylink=cpy (accessed on } \\
30 \text { December 2014). }\end{array}$ \\
\hline Houston Chronicle (2014) & $\begin{array}{l}\text { Houston Chronicle. Freak Tractor Accident Kills Liberty County Man; Houston Chronicle: } \\
\text { Houston, TX, USA, 2014. Available online: www.chron.com/news/houston-texas/ } \\
\text { houston/article/Freak-tractor-accident-kills-Liberty-County-man-5865257.php } \\
\text { (accessed on } 30 \text { December 2014). }\end{array}$ \\
\hline Illinois Extension (2012) & $\begin{array}{l}\text { Illinois Extension. Illinois Farm Relate Fatalities, 1986-2012; Illinois Extension, University of } \\
\text { Illinois: Champaign, IL, USA, 2012. Available online: my.extension.illinois.edu/ } \\
\text { documents/2377131107130713/Illinois\%20Farm\%20Related\%20Fatalities\%201986.pdf } \\
\text { (accessed on } 7 \text { April 2016). }\end{array}$ \\
\hline KFGO (2016) & $\begin{array}{l}\text { Deadly Farm Accident in Douglas County. Fargo, ND, USA. Available online: http: } \\
\text { //kfgo.com/news/articles/2016/nov/12/deadly-farm-accident-in-douglas-county/ } \\
\text { (accessed on } 15 \text { November 2016). }\end{array}$ \\
\hline KMBC (2014) & $\begin{array}{l}\text { KMBC. Marshall Man Dies in Tractor Accident; KMBC: Kansas City, MO, USA, } 2014 . \\
\text { Available online: www.kmbc.com/news/marshall-man-dies-in-tractor-accident/27927770 } \\
\text { (accessed on } 7 \text { April 2016). }\end{array}$ \\
\hline KRCG (2014) & $\begin{array}{l}\text { KRCG. Missouri Man Dies in Tractor Accident; KRCG: New Bloomfield, MO, USA, } 2014 . \\
\text { Available online: http:/ / krcgtv.com/news/local/missouri-man-dies-in-tractor-accident } \\
\text { (accessed on } 30 \text { December 2014). }\end{array}$ \\
\hline
\end{tabular}


KXRA. Man Seriously Injured in Farm Accident near Underwood; KXRA: Alexandria, MN, USA, 2014. Available online:

KXRA (2014) www.voiceofalexandria.com/news/local/man-seriously-injured-in-farm-accident-nearunderwood/article_d71d328e-0e79-11e4-8b2b-001a4bcf6878.html?TNNoMobile (accessed on 30 December 2014).

Lancaster Online. Man, 81, Run over, Killed by Tractor in East Hempfield Township; Lancaster Online: Lancaster, PA, USA, 2013. Available online:

Lancaster Online (2013) www.lancasteronline.com/news/man-run-over-killed-by-tractor-in-east-hempfieldtownship/article_d6831866-c441-57ea-9027-4231f76cdf05.html (accessed on 30 December 2014).

\begin{tabular}{|c|c|}
\hline NIOSH (1992) & $\begin{array}{l}\text { National Institute for Occupational Safety and Health (NIOSH). Fatality Assessment and } \\
\text { Control Evaluation (FACE) Report 9307; NIOSH: Washington, DC, USA, } 1992 .\end{array}$ \\
\hline NIOSH (1996) & $\begin{array}{l}\text { NIOSH. Fatality Assessment and Control Evaluation (FACE) Report 96MO082; NIOSH: } \\
\text { Washington, DC, USA, } 1996 .\end{array}$ \\
\hline NIOSH (1998a) & $\begin{array}{l}\text { NIOSH. Fatality Assessment and Control Evaluation (FACE) Report 98IA037; NIOSH: } \\
\text { Washington, DC, USA, } 1998 .\end{array}$ \\
\hline NIOSH (1998b) & $\begin{array}{l}\text { NIOSH. Fatality Assessment and Control Evaluation (FACE) Report 98MN030; NIOSH: } \\
\text { Washington, DC, USA, } 1998 .\end{array}$ \\
\hline NIOSH (1999) & $\begin{array}{l}\text { NIOSH. Fatality Assessment and Control Evaluation (FACE) Report 99TX38101; NIOSH: } \\
\text { Washington, DC, USA, } 1999 .\end{array}$ \\
\hline NIOSH (2001) & $\begin{array}{l}\text { NIOSH. Fatality Assessment and Control Evaluation (FACE) Report 01CA008; NIOSH: } \\
\text { Washington, DC, USA, } 2001 .\end{array}$ \\
\hline NIOSH (2002) & $\begin{array}{l}\text { NIOSH. Fatality Assessment and Control Evaluation (FACE) Report 02CA010; NIOSH: } \\
\text { Washington, DC, USA, } 2002 .\end{array}$ \\
\hline NIOSH (2005) & $\begin{array}{l}\text { NIOSH. Fatality Assessment and Control Evaluation (FACE) Report 04IA017; NIOSH: } \\
\text { Washington, DC, USA, } 2005 .\end{array}$ \\
\hline NIOSH (2009) & $\begin{array}{l}\text { NIOSH. Fatality Assessment and Control Evaluation (FACE) Report 2008-01; NIOSH: } \\
\text { Washington, DC, USA, } 2009 .\end{array}$ \\
\hline NIOSH (2015) & $\begin{array}{l}\text { NIOSH. Fatality Assessment and Control Evaluation (FACE) Report: Agriculture; NIOSH: } \\
\text { Washington, DC, USA, 2015. Available online: wwwn.cdc.gov/NIOSHFACE/Default. } \\
\text { cshtml?state=ALL\&Incident_Year=ALL\&Category2=0001\&Submit=Submit (accessed on } 3 \\
\text { April 2015). }\end{array}$ \\
\hline Otago Daily Times (2013) & $\begin{array}{l}\text { Otago Daily Times. Wife Backed Over, Killed near Christchurch; Otago Daily Times: Dunedin, } \\
\text { NZ, USA, 2013. Available online: } \\
\text { www.odt.co.nz/news/national/278363/wife-backed-over-killed-near-christchurch } \\
\text { (accessed on } 30 \text { December 2014). }\end{array}$ \\
\hline SnoValley Star (2010) & $\begin{array}{l}\text { SnoValley Star. Logger Taken by Helicopter to Harborview after Tractor Crushes His Leg; } \\
\text { SnoValley Star: Issaquah, WA, USA, 2010. Available online: www.snovalleystar.com/2010/ } \\
\text { 12/07/logger-taken-by-helicopter-to-harborview-after-tractor-crushes-his-leg (accessed } \\
\text { on } 30 \text { December 2014). }\end{array}$ \\
\hline Suzuki Law (2013) & $\begin{array}{l}\text { Suzuki Law. Construction Worker Killed after Being Run over by Tractor; Suzuki Law Offices: } \\
\text { Phoenix, AZ, USA, 2013. Available online: www.suzukilawoffices.com/Blog/2013/March/ } \\
\text { Construction-Worker-Killed-After-Being-Run-Over-.aspx (accessed on } 30 \text { December 2014). }\end{array}$ \\
\hline $\begin{array}{l}\text { Virgin Islands Daily } \\
\text { News (2011) }\end{array}$ & $\begin{array}{l}\text { Virgin Islands Daily News. Tractor Crushes Man to Death at landfill; Virgin Islands Daily } \\
\text { News: St. Thomas, VI, USA, 2011. Available online: www.virginislandsdailynews.com/ } \\
\text { news/tractor-crushes-manto-death-at-landfill-1.1248624 (accessed on } 30 \text { December 2014). }\end{array}$ \\
\hline WLFI (2016) & $\begin{array}{l}\text { WLFI. Fatal Tractor Accident in Newton County; WLFI: West Lafayette, IN, USA, } 2016 . \\
\text { Available online: www.wlfi.com/2016/02/26/fatal-tractor-accident-in-newton-county } \\
\text { (accessed on } 307 \text { April 2016). }\end{array}$ \\
\hline WMC-TV (2010) & $\begin{array}{l}\text { WMC-TV. Man Accidently Backs over One-Year-Old Child with Tractor; WMC-TV: Memphis, } \\
\text { TN, USA, 2010. Available online: www.wbtv.com/story/13123088/man-accidentally- } \\
\text { backs-over-one-year-old-child-with-tractor (accessed on } 30 \text { December 2014). }\end{array}$ \\
\hline
\end{tabular}

\section{References}

1. U.S. National Highway Traffic Safety Administration (NHTSA). Vehicle Rearview Image Field of View and Quality Measurement; NHTSA: Washington, DC, USA, 2011. 
2. U.S. Centers for Disease Control and Prevention. Deaths among Children Aged Less than or Equal to 5 Years from Farm Machinery Runovers-Iowa, Kentucky, and Wisconsin, 1995-1998, and United States 1990-1995; Centers for Disease Control and Prevention: Atlanta, GA, USA, 1999; Volume 48, pp. 605-608.

3. U.S. Occupational Safety and Health Administration (OSHA). 1926.602(a)(9)(ii): Safety and Health Regulations for Construction: Motor Vehicles, Mechanized Equipment, and Marine Operations; Occupational Safety and Health Administration: Washington, DC, USA, 2014. Available online: www.osha.gov/pls/oshaweb/owadisp. show_document?p_table=STANDARDS\&p_id=10769 (accessed on 7 April 2016).

4. Teizer, J.; RAPIDS Laboratory, Ruhr-University Bochum, Bochum, Germany. Personal communication, 22 February 2016.

5. U.S. Bureau of Labor Statistics. National Census of Fatal Occupational Injuries in 2013 (Preliminary Results); U.S. Bureau of Labor Statistics: Washington, DC, USA, 2014. Available online: www.bls.gov/newsrelease/ pdf/cfoi.pdf (accessed on 7 April 2016).

6. U.S. National Institute for Occupational Safety and Health (NIOSH). Agricultural Safety; National Institute for Occupational Safety and Health: Washington, DC, USA, 2014. Available online: www.cdc.gov/niosh/ topics/aginjury (accessed on 7 April 2016).

7. Lancaster Online. Man, 81, Run over, Killed by Tractor in East Hempfield Township; Lancaster Online: Lancaster, PA, USA, 2013. Available online: www.lancasteronline.com/news/man-run-over-killed-by-tractor-in-easthempfield-township/article_d6831866-c441-57ea-9027-4231f76cdf05.html (accessed on 30 December 2014).

8. WMC-TV. Man Accidently Backs over One-Year-Old Child with Tractor; WMC-TV: Memphis, TN, USA, 2010. Available online: www.wbtv.com/story/13123088/man-accidentally-backs-over-one-year-old-child-withtractor (accessed on 30 December 2014).

9. Houston Chronicle. Freak Tractor Accident Kills Liberty County Man; Houston Chronicle: Houston, TX, USA, 2014. Available online: www.chron.com/news/houston-texas/houston/article/Freak-tractoraccident-kills-Liberty-County-man-5865257.php (accessed on 30 Available online: www.chron.com/news/ houston-texas/houston/article/Freak-tractor-accident-kills-Liberty-County-man-5865257.php (accessed on 30 December 2014).

10. U.S. Department of Agriculture (USDA). 2012 Census of Agriculture Highlights. 2014. Available online: https://www.agcensus.usda.gov/Publications/2012/Online_Resources/Highlights/Farm_Demographics/ Highlights_Farm_Demographics.pdf (accessed on 7 April 2016).

11. NIOSH. Fatality Assessment and Control Evaluation (FACE) Report 02CA010; NIOSH: Washington, DC, USA, 2002.

12. Prairie Agricultural Machinery Institute (PAMI). Safe Implement Hitching, A Guide for Safe Connection of Agricultural Tractors to Implements; PAMI: Humboldt, Saskatchewan, Canada, 2011. Available online: http://www.wsps.ca/WSPS/media/Site/Resources/Downloads/Safe_Implement_Hitching Guide.pdf?ext=.pdf (accessed on 10 May 2015).

13. American Society of Agricultural and Biological Engineers (ASABE) Standards. S351: Hand Signals for Use in Agriculture; ASABE: St. Joseph, MI, USA, 2004. Available online: www.asabe.org (accessed on 10 May 2015).

14. NIOSH. Fatality Assessment and Control Evaluation (FACE) Report: Agriculture; NIOSH: Washington, DC, USA, 2015. Available online: wwwn.cdc.gov/NIOSHFACE/Default.cshtml?state=ALL\&Incident_Year=ALL\& Category2=0001\&Submit=Submit (accessed on 3 April 2015).

15. U.S. Occupational Safety and Health Administration (OSHA). Regulations (Standards-29 CFR 1926.21(b)(2)). 2015a. Available online: https://www.osha.gov/pls/oshaweb/owadisp.show_document?p_table= STANDARDS\&p_id=10607 (accessed on 7 April 2016).

16. Ehlers, S.G. Rearward Visibility Issues Related to Agricultural Machinery: Contributing Factors, Potential Solutions. Ph.D. Thesis, Department of Agricultural and Biological Engineering, Purdue University, West Lafayette, IN, USA, 2016.

17. OSHA. Regulations (Standards-29 CFR 1926.601(b)(4)). 2015b. Available online: https://www.osha.gov / pls/oshaweb/owadisp.show_document?p_table=STANDARDS\&p_id=10768\#1926.601(b)(4) (accessed on 7 April 2016).

18. ASABE Standards. SAE J1194: Rollover Protective Structures (ROPS) for Wheeled Agricultural Tractors; ASABE: St. Joseph, MI, USA, 1989. Available online: www.asabe.org (accessed on 23 June 2014).

19. NIOSH. Fatality Assessment and Control Evaluation (FACE) Report 98MN030; NIOSH: Washington, DC, USA, 1998. 
20. OSHA. Enforcement Exemptions and Limitations under Appropriations Act; Occupational Safety \& Health Administration: Washington, DC, USA, 1998. Available online: www.osha.gov/pls/oshaweb/owadisp. show_document?p_table=DIRECTIVES\&p_id=1519 (accessed on 3 April 2015).

21. Sjøflot, L. Big mirrors to improve tractor driver's posture and quality of work. J. Agric. Eng. Res. 1980, 25, 47-55. [CrossRef]

22. Lund, M.; Butters, L. An Investigation and Comparison into Operator Field of Vision for Modern Tractor Cabs; Scientific Papers; University of Agricultural Science and Veterinary Medicine: Buncharest, Romania, 2011; Series A, Vol. LIV.

23. NHTSA. Public Law 110-189, Kids Transportation Safety Act of 2007. In Proceedings of the 110th Congress; National Highway Traffic Safety Administration, Washington, DC, USA, 6 November 2007.

24. NIOSH. Fatality Assessment and Control Evaluation (FACE) Report 04IA017; NIOSH: Washington, DC, USA, 2005.

(C) 2017 by the authors; licensee MDPI, Basel, Switzerland. This article is an open access article distributed under the terms and conditions of the Creative Commons Attribution (CC BY) license (http:/ / creativecommons.org/licenses/by/4.0/). 